\title{
Religion: An Unsolved Problem for the Modern Czech Nation*
}

\author{
OLGA NEŠPOROVÁ** \\ Research Institute for Labour and Social Affairs, Prague
}

ZDENĚK R. NEŠPOR

Institute of Sociology AS CR, Prague

\begin{abstract}
The Czech Republic is widely known as 'the least religious' country in the world and most Czechs are quite proud of that fact. The authors, however, challenge both of these characteristics. Czechs might better be considered unchurched than atheist, with various forms of modern New Age spirituality steadily gaining in popularity. Moreover, their reputation for irreligiosity is somewhat questionable, since it is most often based upon communist (and other more historically deep-rooted) anticlerical notions, while people have little real knowledge of the ideas which they so readily reject. These assertions are based both on quantitative data, provided by census returns and ISSP surveys on religion, and on qualitative data, collected in local ethnographic research in the town of Česká Lípa in northern Bohemia, designed along the lines of the Lancaster University Kendal Project in Great Britain. The Czech population can be divided into three 'blocks', religionists, spiritualists, and atheists/unbelievers, none of which, however, can be considered uniform in terms of membership or truly mutually exclusive. The authors conclude that traditional religionists of various denominations, the followers of New Age movements, and the 'rest' of the population can be seen as three distinctive groups within society and that mutual understanding and acceptance are by no means the norm.
\end{abstract}

Keywords: Czech Republic, 1993-, religion, spirituality, atheism, post-communism, sociology of religion

Sociologický časopis/Czech Sociological Review, 2009, Vol. 45, No. 6: 1215-1237

There are very few nations whose intellectuals have, over such a long period of time, devoted such enormous efforts to discussing the very existence of their nation, the 'purpose' of its being, and the necessity that that nation contribute positively to the development of humankind, as those of the modern Czech nation,

\footnotetext{
* This article was written as part of project No. 403/08/0720 supported by the Grant Agency of the Czech Republic; the funding is gratefully acknowledged.

** Direct all correspondence to: Olga Nešporová, Research Institute for Labour and Social Affairs, Palackého n. 4, 12801 Prague 2, Czech Republic, e-mail: olga.nesporova@vupsv.cz; Zdeněk Nešpor, Institute of Sociology, Academy of Sciences of the Czech Republic, Jilská 1, 11000 Prague 1, Czech Republic, e-mail: zdenek.nespor@soc.cas.cz.
} 
which emerged during the 'spring of nations' in the 19th century. At least since the publication of T. G. Masaryk's The Czech Question (Česká otázka, 1895), Czech intellectuals have devoted a great deal of attention to such issues, as documented in the two thick volumes edited by Miloš Havelka [1995, 2006]. Intellectuals have tended to focus upon the 'unresolved' (often unvoiced) 'problems' of the Czech nation, often attempting to address its discontinuity, the great medieval nation having almost disappeared by the early modern period, necessitating its 'reconstruction' during the 19th century. Three important conservative thinkers, Milan Otáhal, Petr Pithart, and Petr Př́hoda, writing under the pseudonym Podiven - whose verdicts were not very popular among the general public, including other intellectuals emphasise the 'imperfect' social structure of the nation, the backwardness of the Czech population compared to Czech Germans, and the nationalistic struggles aimed at 'cleansing' the Bohemian space, which ended in the tragic displacement / expulsion of the Sudeten Germans after the Second World War [Podiven 1991]. The Czech-born, British social anthropologist Ladislav Holy would add to this list the nation's messy relationship with its 'younger brother', the Slovaks, and its contradictory self-awareness as 'little Czech[s] and [living in] the great Czech nation' [Holy 1996]. Other thinkers on the subject maintain that other relevant 'issues' are pertinent here, yet all of them highlight the modern Czech attitude towards religion as both specific and problematic, to put it euphemistically.

The Czech lands witnessed the Hussite movement in the late Middle Ages, practically the first nation-wide act of opposition to the Roman Catholic Church, and the subsequent spread of the reformation, only then to see Protestantism banned after the Battle of the White Mountain (1620) and the forced re-Catholicisation of the population. Consequently, by the early modern period, the vast majority of Czechs (and Czech Germans) had re-accepted Catholicism, indeed had become deeply 'baroque' Catholic, and any resisting, hidden non-Catholics remained marginal, as did later the modern Protestant churches, which were finally legalised at the end of the 18th century after a century and a half of counterreformation. However, in the 19th century another important shift occurred. The ideal of a modern Czech nation built on its historical, that is, Hussite/Protestant religious identity, and liberal, often anticlerical, values, which questioned the contemporary Catholicism of the majority of Czechs, portrayed the 'old' religion as formal, unworldly, and outdated. Whilst the Austro-Hungarian monarchy had been closely connected with the privileged Catholic state confession (which made desertions somewhat rare), shortly after the fall of the monarchy and the creation of an independent Czechoslovakia in 1918 roughly a million and a half Czechs left the Roman Catholic Church, half of whom subsequently joined the newly established Czechoslovak (Hussite) Church, with the other half choosing to abandon formal religion altogether and stand 'without confession'. Foreign observers at the time spoke of a 'new Czech reformation' [Czakó 1925: 69-79], but it should be seen rather as an out-of-the-church movement connected with Czech nationalism, liberalism, and a general self-awareness of belonging to a 'chosen' nation, the nation which would lead others to a higher, that is, anticlerical level 
of 'humanity'. From that time, if not earlier, the Czechs were very suspicious of church religion and subsequently readily accepted the communist condemnation of churches and religion as constituting the 'opium of the masses', though, importantly, this did not mean that the majority of people lost their religious / spiritual needs. ${ }^{1}$

According to sociological data, the Czech Republic is today seen as one of the least religious countries in the world (together with Estonia and the former GDR); indeed as possibly the least religious [see, for example, Davie 2000; Greeley 2003; Need and Evans 2001], or, alternatively, as a 'laboratory of secularisation' [Fiala 2007]. But such an evaluation must be understood in its wider context, which includes the aforementioned historical reasons for Czech 'churchlessness' [Hamplová and Nešpor 2009]. Czechs should be seen as anticlerical rather than as wholly irreligious, even if they themselves often do not distinguish between the two characteristics, and even though they are generally open to modern holistic forms of spirituality imported from the West after the 1989 Velvet Revolution, it does not always mean that Czech attitudes towards religion/spirituality are the same as those in Western European countries. In this article, the authors would like to examine the contemporary state of (various types of) religion/spirituality in Czech society, devoting particular attention to the 'unresolved problem' of the Czechs and their overwhelmingly negative attitude towards (Christian) church religion, an issue which highlights well the differences between Czech society on the one side and other European societies (both East and West) on the other.

\section{Data sources}

The authors use quantitative data to give a basic description of the religious situation and incidence of various spiritual beliefs in Czech society. In particular, use is made of the Czech data gathered in the two waves of the International Social Survey Programme (ISSP): Religion II (1998) ${ }^{2}$ and Religion III (2008); both surveys were conducted by the Institute of Sociology AS CR. Multi-stage probability random sampling was used to arrive at a representative sample of the adult population aged 18 and over; the research sample numbered 1223 respondents in 1999 and 1512 respondents in 2008. In both cases data were gathered by means of face to face interviews. Unfortunately, the response rate was quite low in both surveys (the lowest of all the Czech ISSP surveys, which was presumably connected with the topic under investigation - religion), 40\% in 1999 and $46 \%$ in 2008 . Weighted data was used, and, significantly, the authors did not discreet the answer 'I do not know' during the analysis stage since they thought that its occurrence was quite

\footnotetext{
1 The development of religion(s) in the Czech lands is well elaborated in Schulze Wessel and Zückert [2009], the sociological measurement of which is presented by Nešpor [2009].

${ }^{2}$ In the Czech Republic fieldwork was conducted the next year, in 1999.
} 
significant in relation to religion and other spiritual beliefs (for instance belief in an afterlife). However, it is important to mention here that the Czech interviewers were instructed not to offer this answer to interviewees if it could be avoided and to use it as sparingly as possible. To determine the reasons for religious belief, use was made of comparative data from the Czech Population and Housing Censuses, gathered by the Czech Statistical Office in 1991 and 2001.

Censuses and/or specialised quantitative surveys on religion provide representative national data, but such data cannot fully cover the substance of the various beliefs represented in Czech society. Therefore, such data must be complemented by means of qualitative or socio-anthropological research, which, in this case, was conducted in Česká Lípa, a medium-sized town (population 39 000) in north Bohemia. The design of the research methods closely followed that used by Paul Heelas, Linda Woodhead and their team in Kendal, a town in northern England [see Heelas and Woodhead 2005]. The Czech team, like their British counterparts, covered three main domains: the church and spiritual milieux and - to a lesser extent, using a street survey - the religious/spiritual attitudes and practices (or their absence) of the people of Česká Lípa as a whole. The 'Kendal methodology' was slightly adjusted to suit the specific characteristics of the Czech environment. Unstructured, open-ended interviews and semi-structured interviews were conducted, audiotaped, transcribed and coded. Interviewees can generally be divided into three groups according to the topics in which the authors were interested and the design of the research: first, (8) leaders of all the churches represented in the town, second, (9) leaders or active participants in the spiritual centres the team was able to trace, and third, ordinary people living in two streets who were willing to talk about religion and spirituality. As far as the street survey is concerned, out of a total number of 114 houses and flats, the team contacted 76 potential informants and ultimately conducted 40 interviews. Interviewing formed the main part of the research and was supplemented by long-term observation (in some cases participative observation) in the town in 2007-2008 which provided comprehensive information on personal and group attitudes and identities, behaviour, relations with local society and with other members of the respective milieu. ${ }^{3}$

The town of Česká Lípa was chosen because it is relatively similar to Kendal: a small to medium-sized town that functions as a regional centre of sorts and in which most, if not all, (types of) Czech religious and spiritual organisations are represented. However, while Kendal can be seen as pars pro toto of contemporary English religion/spirituality, the district of Česká Lípa is one of the most secularised regions of a widely unchurched Czech Republic; moreover, the town itself is even less religious than the local area it serves. On the other hand, many observers (including the inhabitants of Česká Lípa) believe that the lower the influence

\footnotetext{
3 The results of the research were published in full (in Czech) in book length. A comparison is provided with another town, Mikulov in southern Moravia [see Lužný and Nešpor 2008].
} 
of traditional church religion, the more widespread are the new religious and spiritual outlets including the various NRMs and unorganised forms of New Age and spiritual belief. The choice of Česká Lípa was thus intentional with respect to the issue here under investigation, though the town itself cannot be seen as representative of Czech religion/spirituality as a whole.

\section{Religionists and atheists in Czech society}

The communist regime's fight against religion oppressed churches and religionists and at the same time actively supported atheism. The outcome of this fortyyear anti-religious crusade was a clear victory for the regime, principally because they built upon existing anticlerical attitudes and utilised them to great effect. The significance of churches in public life during this period was minimal, regular church attendance was very low, and even the main rites of passage (baptism, confirmation, weddings, and funerals) ${ }^{4}$ were held only on a secular basis by the majority of the population by the end of the 1980s [Babička 2005; Hamplová 2001]. Following the political changes of 1989 there was a short wave of enthusiasm for religion, connected with the newly acquired freedoms [see, e.g., Echikson 1990: 174-189], but it did not last long. The number of people declaring themselves as holding some kind of religious belief dropped significantly between 1991 and 2008 (see Table 1). ${ }^{5}$ According to the most recent data available, more than threefifths of Czechs (63\%) declared themselves as having no religious belief in 2008. Those who said they held some kind of religious belief were predominantly Roman Catholics, who make up approximately 30\% of the population. All the other churches combined cover a mere $5 \%$ of contemporary Czech society (including the $0.2 \%$ of non-Christians). As has already been pointed out, such numbers clearly distinguish the Czech Republic as (one of) the most irreligious countries in the world, comparable only with the former East Germany, Estonia and a small number of other societies.

Unfortunately, it must be admitted - should it ever be allowed in a sociological paper - that one should be careful not to put too much faith in quantitative data. Besides the indisputable fact that there has been a significant decrease in religious belief in Czech society over the last couple of decades, it is evident that there are discrepancies between the data provided by censuses on the one

\footnotetext{
${ }^{4}$ At the end of the 1980s, around one-tenth of Czech youngsters underwent Christian confirmation, one-tenth of weddings were organised by churches (besides the obligatory secular ceremony), and around a quarter of newborns was baptised. In comparison, Christian funerals were held significantly more often - about two-fifths of the deceased. For information on the gradual replacement of Christian funerals by civic services during the 20th century, see Nešporová [2007].

${ }^{5}$ At the same time, attendance at worship remained more or less the same over the two decades, which tends to confirm the 'vogue' character of the Czech 'return to religion' in the early 1990s.
} 
Table 1. Division of Czech society according to religion (in \%)

\begin{tabular}{lcccc}
\hline Church/religious belief & $\begin{array}{c}\text { Census } \\
1991\end{array}$ & $\begin{array}{c}\text { Census } \\
2001\end{array}$ & ISSP 1998 & ISSP 2008 \\
\hline Without religion/Atheist & 39.9 & 59 & 43.7 & 63.3 \\
Roman Catholic Church & 39 & 26.8 & 45.9 & 29.7 \\
$\begin{array}{l}\text { Protestant Church of the } \\
\text { Czech Brethren }\end{array}$ & 2 & 1.1 & 2.6 & 2.8 \\
$\begin{array}{l}\text { Czechoslovak Hussite } \\
\text { Church }\end{array}$ & 1.7 & 1 & 2.7 & 1 \\
Other Christian Churches* & 1 & 0.8 & 2.5 & 0.7 \\
Other/ & 0.2 & 2.5 & 0.7 & 0.2 \\
Other Non-Christian & 16.2 & 8.8 & 2 & 2.3 \\
No answer/Don't know & 100 & 100 & 100 & 100 \\
Total & 10302215 & 10230060 & 1221 & 1513 \\
N & & & & \\
\hline
\end{tabular}

* According to census data, these consisted of: Jehovah's Witnesses, Orthodox Church, Silesian Lutheran Church, Adventists, Greco Catholic Church (in descending order according to the number of members in 2001); all other Christian churches according to ISSP data.

Sources: Czech Statistical Office - Census 1991, 2001; Institute of Sociology AS CR - ISSP 1998, 2008.

hand and the ISSP (the best available source of sociological data on religion) on the other. Religionists seem to be over-represented in the survey data (even if one takes changes over time into account) which tends to cast doubt upon its validity (or representativeness in terms of the issues under investigation whilst 'formal representativeness' is guaranteed). This can probably be understood as a consequence of the low response rate to ISSP surveys on religion; irreligious and nonreligious people might simply refuse to participate in the survey due to the nature of the topic. Aware of this fact, the authors use quantitative data only for illustrative purposes and for indicating certain trends and combine or supplement such data with the results of an in-depth qualitative, albeit more time-consuming, investigation carried out at the local level.

The sociological data clearly show that organised religion and certain religious beliefs are obviously not well-suited to most contemporary Czechs. The only growing religious organisations are non-Christian and/or 'other' inaccurately designated religious groups (the authors draw a comparison between the 1991 and 2001 censuses, as these groups cannot be accurately distinguished in the ISSP survey data). At the same time, the so-called spiritual milieu seems to be as widespread in the Czech Republic as in the West. Unlike Western Europe, however, the trend of growing spirituality is also impacting a considerable proportion of those who declare themselves (churchly) religious but who do not attend church 
Table 2. Church religionists, atheists and the 'category in between' in Czech society, 1998 and 2008 (in \%)

\begin{tabular}{lccc}
\hline & Church religionists & 'Between the two' & Atheists \\
\hline ISSP 1998 & 12.1 & 66.3 & 21.6 \\
ISSP 2008 & 9.7 & 50.4 & 39.9 \\
\hline
\end{tabular}

Source: Institute of Sociology AS CR - ISSP 1998, 2008.

services on a regular basis [Hamplová 2008]. One can clearly distinguish between regular attendees of services of worship (two or three times per month or more), that is, church religionists as such on the one hand and atheists (people without a belief in God, denying both personal and impersonal transcendence) on the other, but the majority of the population, or one-half to two-thirds, would seem to fall somewhere in between the two extremes (see Table 2). Despite the fact that Czechs are stronger opponents of church-organised religion than other Europeans, the very fact of their 'uncertainty', and bricolage religiosity/spirituality is not so surprising since the situation in other countries is not markedly different [see, e.g., Heelas 2002: 359-361]. A comparison of data from the two waves of the ISSP highlights recent developments in the proportions of the various groups, whilst the most striking trend exposed by the data is the growing number of atheists in Czech society. The (church) religious enthusiasm of the early 1990s presumably transformed itself into a kind of spiritual awareness during the 1990s which in its turn had also begun to wane in the first decade of the new millennium.

What then do the Czechs believe in? In the subsequent passages the authors intend to describe the different religious/spiritual attitudes (or opposition to them) among the various groups represented in Czech society: religionists (both regular attendees of services and those merely formally professing church affiliation), atheists (confirmed as well as those who understand atheism as unchurchedness and who are 'somehow' religious/spiritual at the same time), and the especially important 'category in between' (or rather 'categories') along with an outline of the special characteristics of each of these groups and, importantly, of why the 'atheist' group is growing so rapidly.

\section{Development of various beliefs in Czech society}

As the authors have already pointed out, the majority of Czechs do not identify themselves with any church. At the same time, however, they are relatively open to de-traditionalised and explicitly 'churchless' (and often anti-church oriented) forms of transcendence. For example, according to the ISSP 2008, more than twofifths of Czech adults believe in the abilities of fortune tellers and faith healers with God-given healing powers (Table 3). A belief in horoscopes is only a little less popular. Conversely, belief in the afterlife and Heaven is significantly less 
Table 3. Various beliefs in Czech society (with special reference to declared Roman Catholics and atheists) in 2008 (in \%)

\begin{tabular}{|c|c|c|c|c|}
\hline \multirow[b]{2}{*}{ Belief in } & \multirow[b]{2}{*}{ Atheists } & \multicolumn{2}{|c|}{ Roman Catholics } & \multirow[b]{2}{*}{$\begin{array}{l}\text { Total (adult } \\
\text { population) }\end{array}$} \\
\hline & & $\begin{array}{c}\text { Regular } \\
\text { churchgoers }\end{array}$ & $\begin{array}{c}\text { Irregular } \\
\text { churchgoers }\end{array}$ & \\
\hline Fortune tellers & 28.2 & 68.6 & 66.1 & 45.6 \\
\hline Faith healers & 19.4 & 75.6 & 63.8 & 41 \\
\hline Horoscopes & 21.1 & 50 & 52.7 & 35.9 \\
\hline Afterlife & 5.2 & 78.9 & 43.7 & 25.4 \\
\hline Heaven & 2.3 & 81.8 & 39 & 21.8 \\
\hline Reincarnation & 4.2 & 26.8 & 26.1 & 14.5 \\
\hline
\end{tabular}

* 'Regular churchgoers' attend church services at least twice a month; 'irregular churchgoers' attend church services once a month or less.

Source: Institute of Sociology AS CR - ISSP 2008.*

common in Czech society as such beliefs are closely linked to Christian thinking. Indeed, belief in the afterlife is generally very low in contemporary Czech society, ${ }^{6}$ including the non-Christian idea of reincarnation, which is becoming popular across the rest of Europe [cf. Walter 2001; Waterhouse and Walter 2003].

However, a look at the incidence of spiritual beliefs in relation to more traditional church-oriented religious beliefs provides rather interesting results. As one would expect, Roman Catholics ${ }^{7}$ tend to believe much more in the afterlife and Heaven than do atheists (defined here as those who do not believe in God or any other form of transcendence). Nevertheless, surprisingly the number of Roman Catholics who admit an interest in non-Christian supernatural phenomena such as fortune telling, healing, and horoscopes is strikingly high, in fact much higher than among those who declare themselves to be atheist, amongst whom these ideas are also not scarce. Regular church attendance would appear to increase not only the probability of a person believing in traditional Christian ideas such as the afterlife and Heaven, but also raises the chance that a person will believe in faith healers and fortune tellers. Moreover, Roman Catholics who do not attend services regularly (irregular churchgoers attending a service once a month or less) believe more often in fortune tellers, faith healers and horoscopes than they do in the afterlife and Heaven. It can therefore be stated that an avowal of traditional religious belief means more than just belief in Christian ideas of the supernatural and contains many more components than the truly traditional beliefs approved by the church.

\footnotetext{
${ }^{6}$ Belief in the afterlife has dropped significantly in the last decade, see Nešporová [2009].

7 Owing to the small number of cases, it is not possible to analyse the members of other Christian (or non-Christian) groups within the sample, Roman Catholics thus represent the religionist category here.
} 
A belief in some type of supernatural phenomenon is by no means uncommon even among 'dyed-in-the-wool' atheists, among whom roughly a fifth or more admit to believing in fortune tellers, faith healers with 'God-given [!] healing powers', and horoscopes, which would tend to suggest that atheism is often understood in terms of opposition to church religion rather than as the ultimate denial of transcendence.

The authors suggest therefore that a review of the evidence renders the general description of Czechs as atheists (and some Czech minorities as true Christians') somewhat inaccurate and certainly unsatisfactory. At the same time, however, it is unreasonable to claim that each individual has merely his/her own religious attitudes incompatible with those of the rest of the population. Using the local case study of Česká Lípa, the authors try to outline the general sentiments of the three previously broadly defined groups - religionists, spiritualists, and atheists - with regard to religion and/or spirituality.

\section{Case study - Česká Lípa}

The low level of (traditional) religiosity among the inhabitants of Česká Lípa (in comparison with that of the rest of the Czech Republic) can be explained by arguments put forward by classical versions of the secularisation thesis. The town was almost totally re-settled after the Second World War, following the mass expulsion of its former inhabitants (Czech Germans). The process of urbanisation continued in the 1970s and 1980s due to the growth of industry and the establishment of uranium mines nearby. People migrating to the town from other parts of then Czechoslovakia largely lost their religion after relocating, even if they originally came from very religious parts of the country (including 'traditionally religious' Slovak villages). Further, all new settlement was directed principally by the Communist Party with its strong anticlerical attitudes, and thus one of the requirements for potential workers in the well-paid (mining) industry was that they abandon their religious beliefs and behave in a non-religious manner once settled in Česká Lípa. Despite these specific features, which explain to some extent the town's low level of religiosity (which remains the case today), the population of Česká Lípa should be studied with regard to religion as 'normal' Czechs, expressing their ir/religious and/or spiritual needs and sentiments like any other member of the wider community.

\section{Church religiosity}

There are eight established churches in Česká Lípa. All three 'folk' churches, with by far the most members in terms of broader Czech society - the Roman Catholic, Protestant and Czechoslovak Hussite churches - are represented in the town, along with the relatively well-established (but marginal) Adventist Church. New 
religious organisations that have emerged or have seen significant increases in membership since 1989 include the Jehovah's Witnesses, the Unity of the Brethren, the Christian Fellowship, ${ }^{8}$ and the Orthodox Church. The latter formed as a result of recent immigration from post-Soviet countries (mostly Ukraine) and is generally viewed (and it views itself) as a 'foreign element' within the town's religious landscape. Broadly speaking, one can distinguish between the traditional churches, well established in (at least a small section of) society, and missionaryactive new churches that address contemporary issues, possibly more explicitly in Česká Lípa than elsewhere.

Three of the new Czech churches concern themselves extensively with a range of social help programmes, which has drawn a significant number of new converts into their ranks, and they have attempted to provide a new spiritual foundation for 'rootless post-communists', mainly in terms of conducting their own 'historical legitimisation' campaign against the 'secular world'. The Jehovah's Witnesses view themselves as the only true Christians, while the Unity of Brethren and the Christian Fellowship emphasise their (mostly fictional) ties to the traditions of the 15th to early 17th century Czech reformation and 'true' Protestantism. These three 'new' churches claim to present alternatives to a 'godless world' (also true for the Adventists), which, at least rhetorically, they condemn, while members of the 'old' churches prefer to participate normally in the regular social life of the town.

According to the Heelas and Woodhead typology, churches can be divided into different groups as follows (see Scheme 1): the main traditional and wellinstitutionalised churches (Roman Catholic Church, Protestant Church of the Czech Brethren, Czechoslovak Hussite Church) could be termed humanistic since they stress the relationships between this world and transcendence; other well-institutionalised churches, that is, churches which put the emphasis on their organisational structures and a hierarchically arranged community of believers Jehovah's Witnesses, Seventh-day Adventists and the Orthodox Church - belong to another group according to Heelas and Woodhead, stressing the difference between this world and the supernatural, as well as between 'religious people' (members of the respective organisation provided they are not just 'on the way' to being 'rightly religious') and the 'rest of the world'. The final group - made up of the Unity of the Brethren and the Christian Fellowship - is characterised by a strong appreciation of personal religious experience but also holds to the humanistic view that relates this world with transcendence.

Despite the differences in the nature of the various churches, there are features common to all of them. Neither the old, nor the new churches in Česká Lípa assume a significant role in broader civil society, and only rarely does one witness

\footnotetext{
8 This church was established in 2003. Like the Unity of the Brethren, it is a charismatic Protestant church made up of disaffected members of the Unity of the Brethren and new converts.
} 
Olga Nešporová, Zdeněk R. Nešpor: Religion: An Unsolved Problem for the Modern Czech Nation

\section{Scheme 1. Typology of churches in Česká Lípa according to their relationship with the world}

\begin{tabular}{lll}
\hline & \multicolumn{1}{c}{ Churches of humanity } & \multicolumn{1}{c}{ Churches of difference } \\
\hline $\begin{array}{l}\text { Institutionalised } \\
\text { religions/churches }\end{array}$ & $\begin{array}{l}\text { Roman Catholic Church } \\
\text { Protestant Church of the } \\
\text { Czech Brethren } \\
\text { Czechoslovak Hussite }\end{array}$ & $\begin{array}{l}\text { Jehovah's Witnesses. } \\
\text { Seventh-day Adventist } \\
\text { Church } \\
\text { Church }\end{array}$ \\
& $\begin{array}{l}\text { Orthodox Church } \\
\text { Experiential religions/ } \\
\text { churches }\end{array}$ & $\begin{array}{l}\text { The Unity of the Brethren } \\
\text { Christian Fellowship }\end{array}$ \\
\hline
\end{tabular}

anything approaching what might be termed the 'vicarious function' of the church vis-à-vis irregular believers [Davie 1994, 2007]. Religionists indeed live in closed communities, without any interest being shown by the majority of secular society, whether it is convenient to their own beliefs (in the case of the 'new' churches) or not (the 'folk' churches). The latter may - for religious reasons - take an active part in municipal administration, social services, and cultural movements connected in some way with the Christian legacy, but if such participation is on an elected basis, individuals are forced to hide or downplay their religious identity in order to be re-elected. The majority of inhabitants quite simply refuse to have anything to do with matters they perceive as being connected with 'backward' religion. The only religious revival occurred in the late 1980s and early 1990s as a direct reaction to the (envisaged) breakdown of communist ideology and/or social care (in a broad sense). This revival was strong enough to allow the establishment of 'new', 'churches of difference', but it soon lost its social impact, while certain, what might be seen as 'pro-religious', decisions of the post-communist town hall were made for non-religious reasons such as competing with other towns for reasons of civic pride and tourism (the renovation of historical church buildings, subsidies for 'spiritual' - in fact mainly evangelistic - cultural events, charities, etc.).

Only a small percentage of the population of Česká Lípa can thus be labelled religionists sensu stricto, though there is a section of society for whom churches function 'vicariously' (between five and ten per cent). The over-representation of women among religionists is not particularly surprising and corresponds to the trend witnessed throughout contemporary Western Europe. The numbers of attendees at worship on an average Sunday (Saturday in the case of the Adventists) were very low in 2007. In most churches (Adventists, Czechoslovak Hussite Church, Protestant Church of the Czech Brethren, Unity of Brethren, Orthodox Church) fewer than thirty people attended Sunday worship. However, higher participation was recorded in three denominations: the Christian Fellowship 
(about fifty participants), Jehovah's Witnesses (about a hundred and twenty participants) and Roman Catholics (about three hundred participants). It is clear that religionists who gather in smaller groups practice collective worship much more often than those from traditional, larger, and more institutionalised churches; the 'high' number of Roman Catholic attendees must be seen in relation to the fact that this is by far the largest church both in the Czech Republic in general and in Česká Lípa in particular. Only between five and ten per cent of those who, in census returns, declared themselves to be Roman Catholics (or members of other 'folk' churches) in Česká Lípa attend worship regularly.

The institutionalised church scene in Česká Lípa can best be characterised by its small size, relative closeness, and unimportance in public life. It is probably exaggerating to say that it is less than tolerated; a more apt description would be that it is socially neglected. Even though churches and their leaders constantly try to attract more people to their churches, their efforts fall on deaf ears. The church scene is, to all intents and purposes, ignored and is considered to be outside the regular public domain. Moreover, ordinary townspeople are not aware of the differences between particular churches and treat them as one all-embracing block. The situation was depicted by a minister of the Protestant Church of the Czech Brethren thus:

We do not encounter any expressions of hate or aversion; rather we are treated with total disregard. It is a very relaxed attitude, as much as to say, do whatever you like, we do not mind. However, when I offered to help out in one of the hospitals I hit a brick wall, it was very hard. Not so much due to the people, but rather to an attitude like: in Česká Lípa, in northern Bohemia, surely a church minister would not go to the hospital, would he? I am allowed to go there to see my people (church members), that at least is tolerated. But I was there to present my view of the ways in which the hospital might implement a more systematic approach. We are now in the European Union and the hospital should have a European certificate and to obtain such a certificate they need to offer psycho-spiritual care. They are aware of this, but they act, for the time being at least, as if it were a joke. I realised that this was not due to a negative attitude towards me personally, but rather to what I represent. They reject churches, they reject Christianity; people like us should stay out of the wider public domain. Granted, the town hall contributes to church restoration, simply because it is the right thing to do; all the town halls in every part of the country do it, even the communist town halls! Indeed, even the smallest chapels have been lovingly restored. Good work! But they certainly oppose the idea that church religion should become involved in charity or the social, cultural, or political domains; the latter least of all!

The number of active church members is small and religionists (of any kind) are practically separated from the rest of society. The more actively religious they are, the deeper is the gap between them and the rest of society. The same is true - indeed rather more so - with regard to the new religious movements (explicitly religious and organised; New Age phenomena are discussed below). NRMs 
emerged in Česká Lípa, like elsewhere, in the early 1990s, and for a number years enjoyed a significant audience, especially a group known as The Space People, which was established in Česká Lípa, but subsequently all but disappeared.

\section{Unchurched spirituality}

Whilst NRMs constituted one of the relatively short-lived 'vogue' phenomena of the early post-revolution era, during which they regularly captured newspaper headlines (in spite of which a very small number of people actually joined such movements), other forms of modern religion/spirituality, namely New Age and holistic spiritual groups or outlets, were much more successful in terms of attracting followers among the general Czech population. It is difficult to estimate the number of members and/or sympathisers of such groups since they tend to be somewhat unorganised and the great majority of those interested are only 'part-time believers'; in other words they participate in such movements and/or use their services only occasionally. Thus, the authors were able to make direct contact with only an 'active minority' or the 'supply side' of the Česká Lípa spiritual market, while information on other practitioners was incomplete or gathered through intermediaries.

There are at least nine spiritual centres in the town providing healing and/ or spiritual services, and several other individuals who deal with associated goods and/or services. The spiritual scene can be divided into three main categories according to their main focus of attention. The first deals with health issues, the second with general personal spiritual development, and the third concerns itself with attempting to foster an 'unofficial' Christian consciousness in society. The health sector is made up of centres and individuals that provide alternative medicine/treatment for both the body and soul/psyche (e.g. reiki, craniosacral therapy, massage, Tibetan medicine) and provides cures (usually medicines and dietary supplements of herbal or other natural origin). The personal spiritual development sector provides services aimed at providing support for the spiritual aspects of life (e.g. courses to enhance self-awareness, yoga, astrology, numerology, the Tao Tea Room, the Ecology and Spiritual Development Centre). The last and least popular sector consists of two unchurched organisations which aim to broaden Christian consciousness (lectures and meetings promoting Christian/ Roman Catholic values, ${ }^{9}$ the restoration of small Christian historical sites).

Due to the fact that spirituality has spread to mainstream culture, all social types are represented among consumers, and only women are slightly over-

\footnotetext{
9 This group is included in the spiritual milieu as it is deliberately independent of the Church and the presented ideas are not in complete accord with the Church teaching - it is rather a detraditionalised, laic organisation adhering to 'Roman Catholicism as it should be'.
} 
represented. However, there is one important exception: older people, especially those aged 60 and over. There are probably several reasons for this: a higher level of church religiosity among older people, the relatively recent increase in popularity of spirituality, the relative inaccessibility for this age group of knowledge of and advertising for spiritual goods and services (e.g. lack of access to the Internet), low level of social networking (new people are usually recruited via personal contacts), lack of money for such services/items and so on. At least some of these characteristics will change over the course of time due to the ageing of the population, at which time one can expect the expansion of the spiritual market to include older cohorts.

According to providers, people are looking for such spiritual services or goods that can directly help them or their close relatives, primarily in terms of personal health (both physical and psychic) or personal development, and pay scant attention to broader issues such as sustentation and the future of the planet, the Universe, and so forth. Both characteristics show that a shift from 'individualism' to 'subjectivism' [Taylor 1989, 2002], or from 'materialism' to 'post-materialism' [Inglehart 1977, 1990] has not yet occurred, at least in Česká Lípa (which probably highlights the main difference between spiritualism here and in Western Europe). In the mid-1990s Ladislav Holy observed the same situation with respect to ecological values and endeavours in Czech society as a whole [Holy 1996], which may well not be true today. ${ }^{10}$ However, the inhabitants of Česká Lípa certainly seem still to exhibit 'materialistic' and 'individualistic' values. The authors found that particular goods (including 'non-material goods') or services may vary greatly, but with respect to the success of respective organisations/individuals the more expensive the goods or services, the more interest they attract (and the more prosperous their providers). Services provided free of charge, such as lectures or spiritual discussion circles, have been the least successful; simply having to pay is often considered proof of the validity of a particular method, aid, or object.

The most characteristic feature of today's spiritualists in Česká Lípa is, however, their strong opposition to (church) religion; here, to speak of divergence from or indifference to church religion, as one would with the general population, is insufficient. The opposition of spiritualists is more significant since many participants in the holistic milieu are at the same time people who declare themselves to be religious and in some cases are even regular churchgoers! The search for logic here can be (at least partly) satisfied only upon discovering that churchgoers often tend to be only 'part time' believers in holistic, non-Christian forms of transcendence, or in the abilities of their practitioners rather than regular consumers of the respective goods or services. ${ }^{11}$ That is to say that exponents

\footnotetext{
${ }^{10}$ Ladislav Rabušic [2000] highlighted a certain (albeit slight) rise in post-materialism especially amongst the younger population.

${ }^{11}$ It is also possible to add that being religious means in this case predominantly membership in the Roman Catholic Church, which has not only been capable of putting together a strict theological doctrine with various forms of popular religion, but has done so willingly (the situation is similar in the Czechoslovak Hussite Church).
} 
of New Age beliefs in Česká Lípa make every effort to exploit the full repertoire of anticlerical feeling to denounce the ability of churches to deal with transcendence, emphasise the 'authoritarianism' of churches, and proclaim their own 'liberty' and the possibility of choice both in constructing symbolic universes, whose parts are eclectically taken from various sources, and in one's practical daily life. On the other hand, many of those who are more deeply involved in the spiritual milieu are unambiguous followers of particular gurus or resolute supporters of certain ideas, goods, services, etc., but do not experience this orientation in terms of 'suffering' from an external authority.

Such attitudes can be demonstrated for instance by a quotation taken from an interview with a reiki master and follower of Russian spiritual leader Boris Tichanovski:

The Lord, if we can so call him, does not want us to meet in churches and to present offerings and so on. The Church rules the mind. People should feel the Lord inside themselves. He is in us, everywhere within us, is he not? So I do not feel the need to be in any such group [church]. When I see Jehovah's Witnesses standing at the roadside, I always see them as psychologically or even mentally unstable people; they seem to permanently need a leader, don't they? However, one cannot help them; it is their conviction, their belief.

Similar attitudes were common among leaders of the spiritual scene. A further example of sharp opposition to churches and especially to their (assumed) power can be found in comments made by a faith healer and seller of dietary supplements:

In my view, the grounds of church-based religion based are simply flawed, despite the fact that originally such religion might have meant well, since it relies upon its extensive power and authority and this is not good. It does not reconcile itself with either divine or spiritual principles. It is said that to judge is something that God gave up in the name of love. Nobody has the right to judge his fellow man in terms of what he does or how he does it. It may sound strange, but I feel it really is like that. And from this perspective the church [the interviewee sometimes uses the singular form and other times the plural; $\mathrm{ON}+\mathrm{ZRN}]$ does not act spiritually. The church judges, evaluates and asserts its interests and concepts and does not allow man the opportunity to disagree.

The producers or providers of spirituality usually explicitly emphasise the differences between themselves and various churches ('religion'), and the consumers - spiritualists - declare themselves as being 'without religion' or even 'atheist'. ${ }^{12}$

\footnotetext{
${ }^{12}$ It must be mentioned here that such 'spiritualism in a broad sense' first occurred as early as the 19th century as a 'modern belief' (often directed against 'older beliefs'), but it has been somewhat neglected by scholars; see McLeod [2000: Chap. 4].
} 
At the same time, it is clear that the spiritual market in Česká Lípa has for some people become a substitute for their religious needs. Despite its rhetorical irreligiousness, it is 'implicitly' [Bailey 1997] or 'invisibly' [Luckmann 1967] religious, and its transformation into self-reliant existence is slow and arduous. Even if its outer manifestations are similar to those in Western Europe, described by Heelas and Woodhead [2005], partly because many stimuli originated there, its essence and development to date are different. Here the authors would like to stress that there is a gap not only between religionists and spiritualists, but also between the latter and 'the rest' of society, which criticises both religionists and spiritualists for succumbing to 'the opium of the masses'. If Heelas and Woodhead predict that the numbers of participants in the church and holistic milieux in Britain will be equal in some 40 years (both containing between 3\% and $4 \%$ of the population) [Heelas and Woodhead 2005: 149], a similar position has already been reached in Česká Lípa. Various forms of new spirituality began to spread particularly after the 1989 revolution and between $5 \%$ and $10 \%$ of the population can now be considered occasional consumers of 'sold spirituality'. The number of those who consume on a regular basis, that is, those who often take part in spiritual healing or exercise sessions, who buy 'magical stones' or 'spiritual' books, or who consult fortune tellers can be estimated at between $1 \%$ and $2 \%$ of the population, similar to the number who attend church on a weekly basis.

\section{'Atheists': the rest of society}

The two groups discussed above were relatively easy to characterise: religionists are those who declare themselves to be church members or hold particular religious beliefs (religionists in a wider sense) or regular churchgoers (in a narrower sense), and spiritualists those who believe in de-traditionalised holistic, non-Christian transcendence or who do related practices (spiritualists in a wider sense), or who often participate in such practices (in a narrower sense). But who are the others, the by far greater part of the population (not only in Česká Lípa)? One can consider atheists to be those who do not believe in God or any other means of transcendence, as the authors did in the interpretation of the quantitative data, but even atheists sometimes exhibit certain spiritual characteristics (e.g. a belief in the power of horoscopes, healing practices, etc.). These 'unbelievers', which is probably a better way to describe this group than the often over-used 'atheists', are certainly not religionists, but their distinction from the spiritual milieu is somewhat blurred. If one respects their own self-identity, one cannot term them spiritualists even though they share many of their beliefs and even practices. Perhaps the most significant difference is that the spiritualists discussed above are aware of their spiritualism, they characterise themselves as spiritual seekers or something similar, while the rest of the population (minus those who consider themselves truly confirmed atheists) do so usually unconsciously, paying little attention to 'solving' any religious/spiritual problem. They simply ignore 'religion' (and 
everything related to it), despite the fact that they have certain supernatural beliefs and that they occasionally take part in certain spiritual practices.

In an effort therefore to characterise the 'residual group' - in fact the great majority of the population of Česká Lípa - according to participants' attitudes towards religion/spirituality, the authors simply include all those who are not members of the two groups discussed at length earlier in the study. Atheists in the strict sense are those who do not believe in God/transcendence and have no interest in the spiritual milieu. Unbelievers (or atheists in a wider sense) make up the rest of this group. Gathering data on atheism and unbelieving as world views was very difficult due to the fact that atheists and unbelievers are not only unorganised, but do not have any leaders or centres at which they meet (at least in Česká Lípa; there are a few atheist organisations elsewhere in the Czech Republic, but their membership is very small). Despite the difficulty of the research conditions, the authors were able to reveal a number of atheist attitudes by means of face-to-face street-survey interviews with ordinary citizens. However, it must be stressed that even though atheists and unbelievers formed by far the majority of potential informants, many of them categorically refused to take part in research dealing with religion, often stating that they did not want to have 'anything to do with religion'. Moreover, interviews with confirmed atheists were the shortest of any group interviewed, since they usually provided very short negative answers to questions about religious or spiritual beliefs or practices; usually they did not provide any explanation for their opinions. Such interviews followed the following pattern:

Respondent (R): Well, I do not believe. If someone wants to believe, he can.

Interviewer (I): Were you brought up in faith?

R: No.

I: As an unbeliever, does it mean that you think God does not exist?

R: I am convinced he [God] does not exist.

I: And if someone talks about something existing between Heaven and earth?

R: No [laughing].

I: Do you think life ends with death?

R: Well, yes I think so.

I: And what do you think about healers? Do they possess healing abilities?

R: They may have abilities, but I don't know if it works. I have never met any such person so I don't know, but I believe they may have certain healing abilities.

I: Do you think such abilities are supernatural or natural?

R: Probably natural [laughing]. I don't know.

I: I would also like to ask you whether you read horoscopes or things like that.

$\mathrm{R}$ : I do, but rarely. Mostly what is written there does not come true.

I: Do you read horoscopes to know what the future holds in store?

R: No, certainly not. 
I: Do you have any experience with churches or with religious people here in Česká Lípa?

R: No. I have never been interested.

(Man, 40 years of age, occupation: driver)

Out of the 40 persons interviewed, seven denied having any religion or sense of spirituality and stated that they held no beliefs or conducted no practices whatsoever connected with the subject (atheists in the strict sense). They held no belief in God or any other supernatural power. If they gave any explanation for their stance, it pointed, for instance, to the evil in the world or to their having a rational mind as opposed to irrational religious or spiritual thinking:

If there was a God, he would not allow [the bad things] what is happening in the world. There is no God, no matter how people might try to explain his existence.

The next twelve interviewees could be described as unbelievers. They usually labelled themselves 'atheists', but it became evident later that it was generally simply a rejection of Christian churches that led them to see themselves thus. A deeper study of their attitudes towards spirituality revealed that their opinions on the supernatural, the afterlife, and so on, were often positive, and suggested that they participated in certain spiritual practices, like studying horoscopes (not just for fun). At the same time, this group did not distinguish between various faiths, religious practices, and their sources. When asked about religious faith, one interviewee told of his spiritual experiences (in a narrow sense, i.e. conjuring up the spirits). In the majority of interviews, however, prayer, healing practices, and contacting deceased relatives were mentioned in the same breath.

If one leaves aside the religionists and spiritualists, the attitudes of the other respondents towards religion - which for them meant church religion - were surprisingly uniform. Churches were rejected in terms of all the arguments presented by former communist anticlerical propaganda [see Nešpor 2008], and religion was seen as 'an obsolete ideology' and an authoritative, oppressive power at best. However, none stated that they had made any effort to gain a deeper knowledge of church teaching and activities and only a small number had tried to find other spiritual alternatives. 'Illiteracy' in terms of official church or spiritual teaching was thus widespread and in some cases almost absolute. Even those with a degree of spiritual knowledge had, in the main, never attended a church service; they a priori reject religious literature and radio/TV broadcasting on the subject, and are only slightly less suspicious of organised spiritual groups. Moreover, the authors presume that those atheists (both 'strong' and 'weak') who were willing to take part in the research probably tended to be more tolerant of religious or spiritual beliefs than those who categorically refused to be interviewed on the topic. 


\section{Conclusion}

The town of Česká Lípa is far from being representative of the Czech Republic as a whole in terms of religion/spirituality or indeed other characteristics, but this extreme example can make a valuable contribution to a broader understanding of contemporary 'Czech irreligiosity' on a wider scale. According to representative surveys, Czechs are mostly unbelievers and there has been an increase in the number of atheists in the last few years, although many Czechs might be described as falling into a category 'between' (strong) atheism and (regular) church religion. By 'atheism' they mean the rejection of (organised) Christianity, its social impact and often merely its presence in the post-1989 public domain. According to ISSP 2008 data, more than $70 \%$ of respondents resent church influence on voting behaviour, two-thirds its impact on government decision-making, and, despite the relative absence of specifically Christian representation and values in Czech politics, ${ }_{1}^{13}$ one-fifth of the population believes that churches have 'too much power' or 'a lot of power' in Czech society. Moreover, only 13\% of Czechs trust churches, which, interestingly, according to the same survey is significantly fewer than those who profess to be members of a church.

However, despite the majority of Czechs proclaiming to be atheist or nonreligious at best, only a relatively small number are confirmed atheists. The atheist and unbeliever 'group' in Czech society is heterogeneous and many so-called atheists exhibit certain spiritual characteristics. Moreover, this is also true of the other groups described hitherto; religionist and spiritualist groups are by no means uniform in their thinking. Amongst (established) church believers and those deeply involved in spiritual circles, that is those that participate in organised religious/spiritual groups and actively take part in their activities one can see a great variety of attitudes and (to a lesser degree) practices. With the presumable exception of members of small Christian churches (there was only one member of such a church, the Christian Fellowship, involved in the street survey), other 'Christians' or 'organised spiritualists' have almost as many individualised and de-traditionalised religious/spiritual attitudes as the rest of the population. They differ mainly in terms of their positive attitude towards their congregation, including the social ties between its members, and in their willingness to take part in collective religious/spiritual practices. For such reasons, believers and spiritualists sharply criticise 'the rest' of the population both for its '(post-) communist materialism' (i.e. denial/lack of interest in religion/spirituality), and its 'egoism', which, in their opinion, means concentrating on private, selfish concerns.

With the exception of regular churchgoers and some (not all) 'weaker religionists', strong opposition towards churches, both established and new, remains

${ }^{13}$ Despite the fact that there is only one party that represents specifically Christian voters - the Czech People's Party - Christian Democratic Union - it has polled no more than 5\% to $10 \%$ of the total vote in all post- 1989 elections and may well fall below the $5 \%$ threshold for entering Parliament in the next election. 
the norm in Czech society. This is especially true for the older generations, raised during the communist regime, that continue to adhere to the regime's anti-religious attitudes and arguments in contrast to other elements of Marxist ideology which in general were vehemently rejected. The regime might not have been successful in terms of oppressing churches - they survived the regime and still have a small number of followers - but it was successful in its dissemination of anticlerical 'propaganda' and encouragement of 'religious illiteracy'. The majority of Czechs simply do not know much about religion, understand it mainly in terms of 'materialism' and power, and are not interested in changing their attitudes. Transcendence is principally identified with religion and religion with Christianity, particularly with the Roman Catholic Church which in turn is fighting a constant battle to counter communist and, indeed, pre-communist anticlerical propaganda.

Younger people on the whole do not hold such strong antichurch attitudes; rather they simply do not seem to care one way or the other about religion and spirituality. These subjects have no place in their worldview; for example, one interviewee reported - and he was not being flippant - that he had two spiritual activities: techno [music] and Formula One racing! Young people tend to ignore both church religion and spirituality if they come across it, indeed to actively avoid the subject, presumably in many cases following their parents' advice to keep away from churches and especially 'sects'. Viewed in this light, the considerable drop in the number of Czechs who believe in God (or other forms of transcendence), especially amongst the younger cohorts, as borne out by sociological surveys on religion, is understandable.

Non-religiosity, a general lack of interest in religion and spirituality, and the often cited 'modernism' and 'tolerance' of the Czechs hardly suggest that they are neutral as far as religion is concerned. Despite the fact that this post-communist state is officially strictly neutral and both old and new religious/spiritual choices have emerged in society, more the result of foreign than domestic influences, society is divided into three distinct 'blocks': minorities made up of religionists and (deeply involved) spiritualists, and the majority who object to both - which are unable to find common ground. These three blocks - each of them characterised by very limited knowledge of the others - are in a state of mutual hostility, albeit only symbolic in nature on the whole. This would seem to indicate that the Czechs - at least those in small town(s); the situation in larger cities and especially in the capital may be without such hostility - have not yet 'solved' their 'religious problem' and, as far as the majority is concerned, there is no will to do so.

The 'Jacobin version of modernisation', to adopt the phrase used by Shmuel N. Eisenstadt [1999], which has characterised Czech society for decades, is still alive. Whereas in the second half of the 20th century other European countries - with a few exceptions, such as Poland, Slovakia, and certain the prevailingly Orthodox countries in Eastern Europe, where a considerable amount of de-secu- 
larisation took place after the fall of communism - 'secularised' not only religion but also anticlericalism (e.g. state laïcité in France) [Willaime 1996], this has not occurred in the Czech Republic. The 'vogue' wave of interest in religion and spirituality that emerged in the 1990s, broader and longer lasting in the latter case, ended in quite the opposite reaction as far as the majority is concerned, in that they rejected anything labelled religious and - to a lesser degree - spiritual.

This irreligiosity, rather than non-religiosity, in its essence sharply differs from most other post-communist societies in Central and Eastern Europe (as well as from Western countries), including Slovakia, the eastern part of the former Czechoslovakia, even if other characteristics may seem similar [see, e.g., Need and Evans 2001; Pollack 2003; Social Compass 2002: 4]. If this national irreligiosity has not waned twenty years after the Velvet Revolution and is being adopted, albeit for different reasons, by the younger generation, one must assume that the trend is unlikely to be reversed in the near future. Furthermore, since the poorly supported churches and relatively marginal spiritual outlets are unable to find the human and other resources required to ensure continuing development, they are likely to face an uncertain future at best, being 'mothballed' according the secular world's wishes.

Olga NeŠPOROVÁ is a researcher at the Research Institute for Labour and Social Affairs in Prague. She holds a PhD in social anthropology from Charles University, the Faculty of Humanities. Her main research interests include changes within the family, attitudes towards death, last rites, values, and the religiosity of contemporary society.

ZDENĚK R. NEŠPOR is a sociologist and historian, a senior researcher at the Institute of Sociology of the Academy of Sciences of the Czech Republic, and an associate professor at the Faculty of Humanities, Charles University. He specialises in the history and sociology of religion, economic sociology, and social anthropology. He has published a hundred scientific papers, both in the Czech Republic and abroad, and a dozen monographs, most recently on the attitudes of Czech intellectuals towards religion in the 20th century (Ne/náboženské naděje intelektuálů [Ir/religious Hopes of Intellectuals], Prague 2008), and The Encyclopedia of Protestant Churches in the Czech Lands (Prague 2009).

\section{References}

Babička, Václav. 2005. 'Vývoj katolické religiozity v Českých zemích v letech 1949-1989.'

(Shifts in Catholic Religiosity in the Czech Lands from 1949 to 1989) Sborník archivnich prací 55 (2): 379-506.

Bailey, Edward. 1997. Implicit Religion in Contemporary Society. Kempen: Kok Pharos. 
Czakó, Ambrose. 1925. The Future of Protestantism with Special Reference to South-eastern Europe. London: G. Allen \& Unwin.

Davie, Grace. 1994. Religion in Britain since 1945. Believing without Belonging. Oxford: Blackwell.

Davie, Grace. 2000. Religion in Modern Europe. A Memory Mutates. Oxford: Oxford UP.

Davie, Grace. 2007. The Sociology of Religion. Los Angeles - London: Sage.

Echikson, William. 1990. Lighting the Night. Revolution in Eastern Europe. New York: W. Morrow.

Eisenstadt, Shmuel N. 1999. Fundamentalism, Sectarianism, and Revolution. The Jacobin Version of Modernity. Cambridge: Cambridge UP.

Fiala, Petr. 2007. Laboratoř sekularizace. Náboženství a politika v ne-náboženské společnosti: český prípad. (Laboratory of Secularisation. Religion and Politics in a Non-religious Society: The Czech Case) Brno: CDK.

Greeley, Andrew M. 2003. Religion in Europe at the End of the Second Millennium. New Brunswick - London: Transaction.

Hamplová, Dana. 2001. 'Institucionalizované a neinsticionalizované náboženství v českém poválečném vývoji.' (Institutionalised and Non-institutionalised Religion in Czech Society) Soudobé dějiny 8 (2-3): 294-311.

Hamplová, Dana. 2008. ‘Čemu Češi věří: Dimenze soudobé české religiosity.' (What Do Czechs Believe In? Dimensions of Contemporary Czech Religiosity) Sociologický časopis / Czech Sociological Review 44 (4): 703-724.

Hamplová, Dana and Zdeněk R. Nešpor. 2009. 'Invisible Religion in a "Non-believing" Country. The Case of the Czech Republic.' Social Compass 56 (4) (forthcoming).

Havelka, Miloš. 1995. Spor o smysl českých dějin. 1895-1938. (Dispute over the Meaning ofxCzech History. 1895-1938) Prague: Torst.

Havelka, Miloš. 2006. Spor o smysl českých dějin. 1938-1989. Posuny a akcenty české otázky. (Dispute over the Meaning of Czech History. 1938-1989. Shifts and Accents of the Czech Question) Prague: Torst.

Heelas, Paul 2002. 'The Spiritual Revolution: From "Religion" to "Spirituality".' Pp. 357-377 in Religions in the Modern World: Traditions and Transformations, edited by Linda Woodhead, Paul Fletcher, Hiroko Kawanami and David Smith. London - New York: Routledge.

Heelas, Paul, Linda Woodhead, Benjamin Steel, Bronislaw Szrszynski and Karin Tusting. 2005. The Spiritual Revolution. Why Religion is Giving Way to Spirituality. Malden - Oxford: Blackwell.

Holy, Ladislav. 1996. The Little Czech and the Great Czech Nation. National Identity and Post-Communist Social Transformation. Cambridge: Cambridge UP.

Inglehart, Ronald. 1977. The Silent Revolution. Changing Values and Political Styles among Western Publics. Princeton: Princeton UP.

Inglehart, Ronald. 1990. Culture Shift in Advanced Industrial Societies. Princeton: Princeton UP.

Luckmann, Thomas. 1967. Invisible Religion. The Problem of Religion in Modern Society. New York: Macmillan.

Lužný, Dušan, Zdeněk R. Nešpor, Eleanóra Hamar, Dana Hamplová, Lucie Hlavinková, Ela Klementová, Olga Nešporová, Gábor Oláh, Michaela Ondrašinová, Barbora Polifková and Radek Tichý. 2008. Náboženství v menšině. Religiozita a spiritualita $v$ současné české společnosti. (Religion as a Minority. Religion and Spirituality in Contemporary Czech Society) Prague: Malvern.

McLeod, Hugh. 2000. Secularization in Western Europe, 1848-1914. London: Palgrave Macmillan. 
Need, Ariana and Geoffrey Evans. 2001. 'Analysing Patterns of Religious Participation in Post-communist Eastern Europe.' British Journal of Sociology 52 (2): 229-248.

Nešpor, Zdeněk R. 2008. 'Ideologické nástroje ateizace české společnosti v letech 1948-1989.' (Ideological Tools for the Atheisation of Czech Society in the Years 1948 to 1989) Církeuní dějiny 1 (1): 36-63.

Nešpor, Zdeněk R. 2009. ‘Die Verwandlungen der tschechischen (Nicht)Religiosität im 20. Jahrhundert im Lichte der soziologischen Forschungen.' Historisches Jahrbuch 129: (forthcoming).

Nešporová, Olga. 2007. 'Smrt, umírání a pohřební rituály v české společnosti ve 20. století.' (Death, Dying and Last Rites in Czech Society in the 20th Century) Soudobé dějiny 14 (2-3): 354-378.

Nešporová, Olga. 2009. 'Smrt jako konec nebo začátek? O (ne)víře v posmrtný život.' (Death as an End or as a Beginning? On (Not) Believing in the Afterlife) Lidé města / Urban People 11 (3): 463-491.

Podiven [Milan Otáhal, Petr Pithart, Petr Př́hoda]. 1991. Češi v dějinách nové doby. Pokus o zrcadlo. (Czechs in Modern History. A Mirror) Prague: Rozmluvy.

Pollack, Detlef. 2003. 'Religiousness Inside and Outside the Church in Selected PostCommunist Countries of Central and Eastern Europe.' Social Compass 50 (3): 321-334.

Rabušic, Ladislav. 2000. 'Je česká společnost "postmaterialistická"?' (Is Czech Society 'Post-materialist'?) Sociologický časopis/Czech Sociological Review 36 (1): 3-22.

Schulze Wessel, Martin and Martin Zückert (eds.). 2009. Handbuch der Religions- und Kirchengeschichte der böhmischen Länder und Tschechiens im 20. Jahrhundert. München: Oldenbourg.

Taylor, Charles. 1989. Sources of the Self. The Making of Modern Identity. Cambridge: Cambridge UP.

Taylor, Charles. 2002. Varieties of Religion Today. William James Revisited. Cambridge - London: Harvard UP.

Walter, Tony. 2001. 'Reincarnation, Modernity and Identity.' Sociology 35 (1): 21-38.

Waterhouse, Helen and Tony Walter. 2003. 'Reincarnation Belief and the Christian Churches.' Theology 106: 20-28.

Willaime, Jean-Paul. 1996. 'Laïcité et religion en France.' Pp. 153-171 in Identités religieuses en Europe, edited by Grace Davie and Danièle Hervieu-Léger. Paris: La Découverte. 